
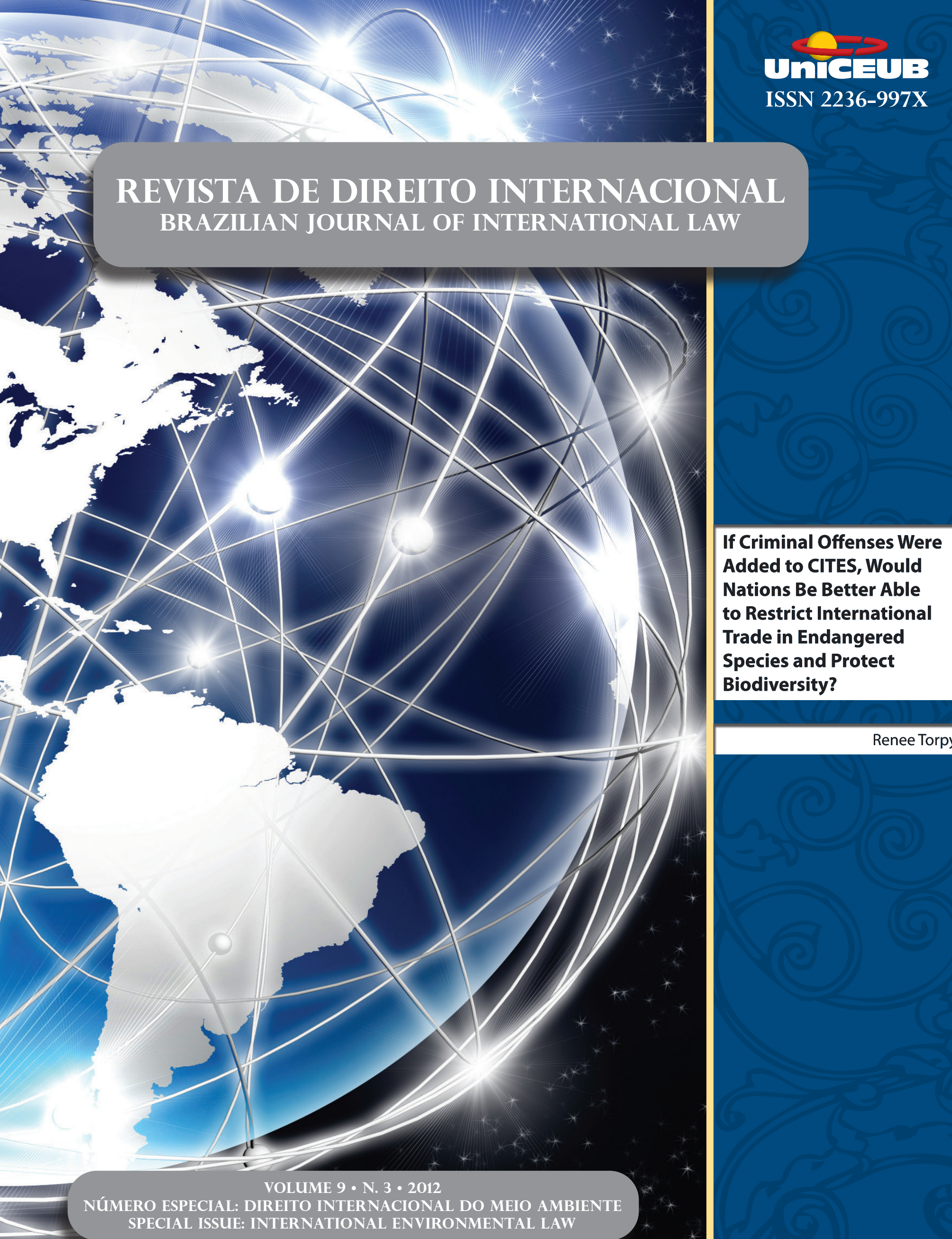


\title{
If Criminal Offenses Were Added to CITES, Would Nations Be Better Able to Restrict International Trade in Endangered Species and Protect Biodiversity?*
}

\begin{abstract}
We often hear the world is shrinking due to technology, but how can the internet affect illicit international trade in endangered species products? There are such small risks with being involved with illegal trade that something needs to be done to deter people. The Convention on International Trade in Endangered Species of Wild Fauna and Flora ("CITES") is inadequate to deal with present problems. However, there are numerous solutions on the dealing with international trade of endangered species products, each with their own challenges.
\end{abstract}

Keywords: Wildlife traffickin 2. CITES3. Endanger Animals4. International Trade5. Biodiversity.

* Artigo recebido em 24/01/2013. 


\section{Introduction: How Crimes Threaten Endangered Species and Biodiversity}

The United Nations General Assembly met in New York on September 24, 2012, for its $67^{\text {th }}$ annual meeting and for the first time poaching and the illicit trafficking of wildlife products were raised. ${ }^{2}$ Illicit international trade in endangered species products, such as rhino horn, elephant ivory and tiger parts, is growing rapidly. ${ }^{3}$ It is now estimated to be worth 16-27 billion US dollars per year globally. ${ }^{4}$ Gabon's President Ali Bongo said, "Such organized crime is increasingly affecting the environment and biodiversity through poaching and illegal fishing."5 Wendy Elliott, the World Wide Fund (WWF) Global Species Program Manager, commented on how wildlife trafficking can have severe consequences for people and the environment despite this, many governments do not consider it a serious crime. ${ }^{6}$

The illegal wildlife trade can affect the natural resources and environments of importing and exporting countries. ${ }^{7}$ Two potential environmental harms of the illegal trade include: (1) the risk of losing endangered species forever and (2) reducing biodiversity. ${ }^{8}$

Conservation groups claim that illegal trafficking is "the number one threat to the survival of endangered species." The International Fund for Animal Welfare (IFAW) states: "Worldwide, 7,725 species of animals, from insects and birds to gorillas, elephants and rep-
2 UN recognizes wildlife crime as threat to rule of law, World Wide Fund Global, http://wwf.panda.org/?206293/UN-recognizes-wildlife-crime-as-threat-to-rule-of-law (last visited Oct. 30, 2012).

3 UN recognizes wildlife crime as threat to rule of law, World Wide Fund Global, http://wwf.panda.org/?206293/UN-recognizes-wildlife-crime-as-threat-to-rule-of-law (last visited Oct. 30, 2012).

4 ICCWC launches wildlife and forest crime toolkit, The Convention on International Trade in Endangered Species of Wild Fauna and Flora (Jul. 25, 2012) http://www.cites.org/ eng/news/pr/2012/20120725_ICCWC_toolkit.php (last visited Oct. 30, 2012).

5 UN recognizes wildlife crime, Supra. note 1.

6 Id.

7 Threats: Illegal Wildlife Trade, World Wide Fund Global, http://worldwildlife.org/threats/illegal-wildlife-trade (last visited Oct. 30, 2012).

8 Unsustainable and illegal wildife trade, World Wide Fund Global, http://wwf.panda.org/about_our_earth/species/ problems/illegal_trade/ (last visited Oct. 30, 2012).

9 Elizabeth Batt, Internet wildlife trading biggest threat to endangered species, Digital Journal (Sept. 4, 2012), http://digitaljournal.com/article/332117 tiles, are considered at risk of extinction. That's $20 \%$ of all known mammal species and $12 \%$ of known species of birds threatened with being lost forever." ${ }^{10}$ Since the Internet has become the world's biggest marketplace, which is unregulated and anonymous, it provides an easy opportunity for criminal activity and transactions in illicit trade in wildlife. ${ }^{11}$ The trade has become "so great that it is now estimated to be second only to illegal trafficking in drugs and weapons." 12 The International Fund for Animal Welfare (IFAW), released a report in 2005 called Caught in the Web: Wildlife Trade on the Internet; in it the group found on eBay more than 9,000 wild animals and animal products for sale. ${ }^{13}$ IFAW did a follow-up report in 2007 titled Bidding for Extinction. ${ }^{14}$ The results reveal a shocking level of trade, especially on eBay regarding ivory where more than $90 \%$ of the listings investigated breached the stated ivory listing policies of the respective eBay websites. ${ }^{15}$ Then in 2008, the IFAW started the largest investigation the organization had ever attempted in order to understand the scale of the Internet wildlife trade: Killing with Keystrokes: An Investigation of the Illegal Wildlife Trade on the World Wide Web, and recorded 7,122 online auctions, advertisements and classifieds, with an advertised value of US $\$ 3.87$ million. ${ }^{16}$ IFAW has continued to research and in 2011, released Killing with Keystrokes 2.0: IFAW's investigation into the European Online Ivory Trade, in which more than 660 items (of which $98 \%$ failed to comply with website policies or provide evidence of legality) were listed in just two weeks. ${ }^{17}$

As a result, endangered animal populations are dwindling rapidly. Illegal selling of endangered species

\footnotetext{
${ }^{10}$ Fighting wildlife trade, International Fund for Animal Welfare, http://www.ifaw.org/united-states/our-work/fightingwildlife-trade (last visited Oct. 30, 2012).

${ }^{11}$ International Survey Bidding For Extinction, International Fund for Animal Welfare, http://www.ifaw.org/sites/default/ files/Report\%202007\%20Bidding\%20for\%20Extinction.pdf ${ }^{12} \mathrm{Id}$.

${ }^{13}$ Caught in the web: Wildlife trade on the Internet, International Fund for Animal Welfare, 1 (Jul. 2006), http://www.ifaw. org/sites/default/files/Report\%202005\%20Caught\%20in\%20 the $\% 20$ web\%20UK.pdf

${ }^{14}$ Bidding for extinction, supra. note 10.

${ }^{15}$ Id.

${ }^{16}$ Killing with Keystrokes 2.0, International Fund for Animal Welfare, (Jul. 26, 2012), http://www.ifaw.org/sites/default/ files/FINAL\%20Killing\%20with\%20Keystrokes\%202.0\%20 report\%202011.pdf

${ }^{17} \mathrm{Id}$.
} 
is just not online but at local markets and stores. ${ }^{18}$ The Roti Island Snake-necked turtle was discovered in eastern Indonesia during 1994 and is so sought after in the international pet trade market that the species has become extinct in the wild. ${ }^{19}$ Also, with traditional medicine becoming more popular, the trade in rare species has increased. ${ }^{20}$ For example, the Asian pangolin (also referred to as a scaly anteater because this burrowing mammal is covered in tough, overlapping scales and eats ants and termites using its sticky tongue) is being poached for use in traditional Chinese medicine causing their populations to rapidly decline. ${ }^{21}$

The increasing demand for animals for pets and medicine is just not causing localized extinctions, but also emptying ecosystems worldwide. ${ }^{22}$ Biological diversity (biodiversity), or the variability of life on Earth, is how to ensure that our standard of life continues. ${ }^{23}$ It includes the variability of plants, animals and other organisms, the genetic differences between species and the variety of them within ecosystems. ${ }^{24}$ Biodiversity is important for many reasons, such as it provides economic benefits, protects human health and safety, and offers recreational or aesthetic enjoyment. ${ }^{25}$ Biodiversity also supplies indirect benefits to humans, which are often taken for granted, such as drinkable water, clean air, and fertile soils. ${ }^{26}$ So, when animal populations decrease or become extinct, it disrupts normal function and disrupts these ecological processes, which we are dependent on. ${ }^{27}$

${ }^{18}$ Stop Illegal Wildlife Trading Project, Endangered Species International, Inc., http://www.endangeredspeciesinternational.org/project_illegaltrade.html (last visited Oct. 30, 2012).

${ }^{19} \mathrm{Id}$.

${ }^{20} \mathrm{Id}$.

${ }^{21}$ Threats, Save Pangolins, http://www.savepangolins.org/ threats/ (last visited Oct. 30, 2012).

${ }^{22}$ Illegal Wildlife Trade, Conservation International, http:// www.conservation.org/learn/biodiversity/species/wildlife_ trade/Pages/wildlife_trade.aspx (last visited Oct. 30, 2012).

${ }^{23}$ Sustaining Life on Earth: How the convention on Biodiversity Promotes Natural and Human Well-Being, Secretariat of the Convention on Biological Diversity (Apr. 2000), http://www. cbd.int/iyb/doc/prints/cbd-sustain-en.pdf

${ }^{24} \mathrm{Id}$.

${ }^{25}$ Why is Biodiversity Important?, Cape Nature, http://www. capenature.co.za/biodiversity.htm? sm [p1] [category] $=595$ (last visited Oct. 30, 2012).

${ }^{26}$ Biodiversity, Global Environment, http://www.admwebstudios.co.uk/Biodiversity1.htm (last visited Oct. 30, 2012).

${ }^{27} I d$.

The international community is trying to reverse these effects by adopting the Convention on International Trade in Endangered Species of Wild Fauna and Flora (“CITES”). ${ }^{28}$ However, there are deficiencies in CITES and the problem of wildlife trafficking is still growing. If provisions were added to CITES, criminalizing the acts in the treaty, would nations be better capable of restricting international trade to protect endangered species and biodiversity? To define and prosecute these crimes the following models could be used: (1) The Convention Model, (2) The Ad Hoc Tribunal Model, or (3) The Treaty/ Permanent Tribunal Model. Each of the models will be evaluated by their advantages and disadvantages, to determine which would be best suited to restricting international trade to protect endangered species and biodiversity.

\section{Regulation of International Wildlife Trade (CITES)}

Environmental problems were viewed as primarily domestic concerns until the 1960's. ${ }^{29}$ Then in the 1960's, multiple international agreements were signed because of the need for international cooperation regarding environmental issues. ${ }^{30}$ In 1963, the General Assembly of International Union for Conservation of Nature (IUCN) decided that there was a definite need for regulating export, transit and import of rare or threatened wildlife and wildlife products internationally. ${ }^{31}$ Ten years later, in 1973, the United States hosted a Conference in Washington D.C. to adopt a wildlife trade convention in which a draft was provided for consideration, based on the latest IUCN draft. ${ }^{32}$ The CITES treaty was adopted on March

\footnotetext{
${ }^{28}$ Convention on International Trade in Endangered Species of Fauna and Flora, Mar. 3, 1973, 27 U.S.T. 1087, 1087 [hereinafter CITES].

${ }^{29}$ Edith Brown Weiss, International Environmental Law: Contemporary Issues and the Emergence of a New World Order, 81 GEO. L.J. 675, 677 (1993), available at http://heinonline. org/HOL/LandingPage? collection=journals \&handle=hein. journals/glj81\&div $=35 \&$ id $=\&$ page $=$

${ }^{30} \mathrm{Id}$. at 678.

${ }^{31}$ Trade Measures in Multilateral Environmental Agreements, The World Conservation Union on the Effectiveness of Trade Measures Contained in The Convention on International Trade in Endangered Species of Wild Fauna and Flora (Sept. 11, 2000), http://www.cites.org/common/prog/economics/ iucn-trademeasuresinCITES.pdf

${ }^{32} \mathrm{Id}$.
} 
3, 1973 by 88 countries and entered into force on July 1, $1975 .{ }^{33}$ The number of countries ratifying the treaty has continued to grow with The Kingdom of Bahrain being the official 176th party, on August 23, 2012, to the Convention. ${ }^{34}$ There are also, at least five States who are currently considering joining the Convention. ${ }^{35}$ CITES is one of the world's most powerful tools for biodiversity conservation through the regulation of trade in wild fauna and flora. ${ }^{36}$ The treaty is viewed by environmentalists as an important legal solution for an international environmental problem. ${ }^{37}$

The primary purpose of the convention is to "ensure that international trade in specimens of wild animals and plants does not threaten their survival." 38 In other words, CITES allows trade, but regulates it, in order to prevent extinction of animal and plant species. Although it may seem that CITES is trying to promote species conservation, it only has jurisdiction over international trade. ${ }^{39}$ "CITES regulates international trade in close to 35,000 species of plants and animals, including their products and derivatives, ensuring their survival in the wild with benefits for the livelihoods of local people and the global environment." 40

The Convention does not appear to provide a holistic approach to species conservation, but addresses only international trade threats. ${ }^{41}$ To achieve its objective, there are two approaches. ${ }^{42}$ First, species that are threatened with extinction and which are or may be affected

${ }^{33} \mathrm{Id}$.

${ }^{34}$ CITES welcomes Bahrain as its 176th Member State, The Convention on International Trade in Endangered Species of Wild Fauna and Flora (Sept. 4, 2012) http://www.cites.org/ eng/news/pr/2012/20120904_bahrain.php

${ }^{35} \mathrm{Id}$.

${ }^{36} I d$.

${ }^{37}$ Edith Brown Weiss, International Environmental Law: Contemporary Issues and the Emergence of a New World Order, 81 GEO. L.J. 675, 677 (1993) http://heinonline.org/HOL/ LandingPage? collection $=$ journals $\&$ handle $=$ hein.journals $/$ glj81\&div=35\&id $=$ \&page $=$

38 What is CITES?, Convention on International Trade in Endangered Species of Wild Fauna and Flora, http://www.cites. org/eng/disc/what.php (last visited Oct. 30, 2012).

39 Trade Measures in Multilateral Environmental Agreements, Supra. note 29.

${ }^{40}$ CITES welcomes Bahrain as its 176th Member State, Supra. note 32 .

41 Trade Measures in Multilateral Environmental Agreements, Supra. note 29.

${ }^{42}$ Trade Measures in Multilateral Environmental Agreements, Supra. note 29. by trade are strictly regulated. Secondly, it ensures that species which are not currently threatened with extinction do not become so as a result of un-controlled trade. ${ }^{43}$

The treaty has a permit system for exporting and importing regulated wildlife. ${ }^{44}$ "The CITES permit system seeks to ensure that international trade in listed species is sustainable, legal and traceable." ${ }^{45}$ There must be at least one "management authority" for each state who takes responsibility for administering the permit system and at least one "scientific authority" to advise on the effects of trade on the species. ${ }^{46}$ The permits should be granted only when the "scientific authority" of the exporting state has determined that the exportation of a particular specimen will not be detrimental to the survival of the species as required by CITES. ${ }^{47}$ Also, the "management authority" of the exporting state has to be satisfied that the specimen was not obtained in violation of national wildlife protection laws. ${ }^{48}$ In addition, the "management authority" is also responsible for making sure that the specimen is living and that it is prepared and shipped in a manner that is adequate to prevent harm to the specimen. ${ }^{49}$

The treaty is separated into three appendices for the regulated plant and animal species, depending on the degree of protection a particular species needs. ${ }^{50}$ The state is required by CITES to determine which of the appendices applies to a particular species by determining: (1) if trade in a particular species can continue without harm to the species, (2) if trade must be closely regulated, or (3) if it must stop in order to prevent extinction of that species. $^{51}$

${ }^{43} I d$.

${ }^{44}$ Endangered species, CITES, endangered wildlife, plants, exotic skins and animals, U.S. Customs and Border Protection, https://help.cbp.gov/app/answers/detail/a_id/64/ /endangered-species,-cites,-endangered-wildlife,-plants,-exoticskins-and-animals (last visited Oct. 30, 2012).

${ }^{45}$ CITES welcomes Bahrain as its 176th Member State, Supra. note 32 .

${ }^{46}$ How CITES Works, Convention on International Trade in Endangered Species of Wild Fauna and Flora, http://www.cites. org/eng/disc/how.php (last visited Oct. 30, 2012).

${ }^{47} \mathrm{Id}$.

${ }^{48} \mathrm{Id}$.

${ }^{49}$ How CITES Works, Convention on International Trade in Endangered Species of Wild Fauna and Flora, http://www.cites. org/eng/disc/how.php (last visited Oct. 30, 2012).

${ }^{50}$ Rosalind Reeves, Policing International Trade in Endangered Species: The CITES Treaty and Compliance (2002), at 29-31.

${ }^{51}$ Id. 
Species that are in serious danger of extinction are in Appendix I. ${ }^{52}$ Usually trade in these species is not permitted, unless there are exceptional circumstances. ${ }^{53}$ For example, there are five species of rhino that are included in the CITES Appendices. ${ }^{54}$ The Javan, Sumatran and Indian rhinos that are found in Asia and are listed in Appendix I, but international trade in any rhino horn is banned. ${ }^{55}$ United Nations TV, and the Secretariat of the CITES released the film "Rhino Under Threat" to show the brutality of the current spike in illegal killing of rhino and the impact it is having on local communities. ${ }^{56}$ The film investigates what is causing the demand for rhino horn in Asia to go up and how national authorities are fighting this crime. ${ }^{57}$

Species where trade of specimens must be carefully controlled both for purposes of sustainable development and to ensure that the species does not become threatened are listed in Appendix II. ${ }^{58}$ Also species that closely resemble Appendix I species are listed in Appendix II because the look-alike species need to be monitored to prevent disguising species as non-regulated wildlife. ${ }^{59}$ An example would be the Patagonian Toothfish and the Antarctic Toothfish. ${ }^{60}$ As whole fish, they are very similar in appearance and in filleted form are indistinguishable. ${ }^{61}$ The two species of fish are not distinguished in trade and therefore if one was to be listed in the CITES Appendix

${ }^{52} \mathrm{Id}$. at 29 .

${ }^{53}$ How CITES Works, Supra. note 44.

54 'Rhinos under threat' film première in Rio, The Convention on International Trade in Endangered Species of Wild Fauna and Flora (Jun. 18, 2012), http://www.cites.org/eng/news/ pr/2012/20120618_rhinos_under_threat_rio.php

${ }^{55} \mathrm{Id}$.

${ }^{56} I d$.

${ }^{57}$ Rhinos under threat' film première in Rio, The Convention on International Trade in Endangered Species of Wild Fauna and Flora (Jun. 18, 2012), http://www.cites.org/eng/news/ pr/2012/20120618_rhinos_under_threat_rio.php.

${ }^{58}$ The CITES Appendices, The Convention on International Trade in Endangered Species of Wild Fauna and Flora, http:// www.cites.org/eng/app/index.php (last visited Oct. 30, 2012).

${ }^{59} \mathrm{Id}$.

${ }^{60}$ Anna Willock, Administrative and Monitoring Implications of listing and down-listing of commercially-exploited aquatic species, including the implications of Annex 4 of Resolution Conf. 9.24, TRAFFIC International, http://www.cites.org/ eng/news/meetings/ifs-05/IFS05-TRAFFIC-paper.pdf (last visited Oct. 30, 2012).

${ }^{61} \mathrm{Id}$. the other should also be considered to be listed under the look a-like provisions. ${ }^{62}$

Species that are already regulated in some states but where the cooperation of other countries to prevent unsustainable or illegal exploitation is needed are listed in Appendix III. ${ }^{63}$ For example, Canada banned commercial walrus hunting in $1931 .^{64}$ Then in 1975 , Canada added the walrus to CITES with the intent to monitor levels of international trade in walrus parts such as raw and worked ivory, worked bone, hides, bacula and other raw bones, etc. ${ }^{65}$

The Secretariat and the Conference of the Parties are the two original international bodies. ${ }^{66}$ The CITES Secretariat is administered by United Nations Environment Programme (UNEP), which is responsible for its general coordination and administration. ${ }^{67}$ Some of its functions include preparing annual reports, making recommendations on legislation, and undertaking scientific and technical studies. ${ }^{68}$

The Conference of the Parties (COP) has participants from all CITES Parties as well as non-governmental organizations. ${ }^{69}$ The non-governmental organizations carry out several key functions in the CITES process such as providing technical information, advocacy, donors, potential partners in implementing decisions and partners in projects carried out by the Secretariat. ${ }^{70}$ The COP is responsible for adopting amendments, making recommendations for improving the effectiveness of the Convention

${ }^{62} \mathrm{Id}$.

${ }^{63}$ The CITES Appendices, Supra. note 55.

${ }^{64}$ Walrus, Seaworld, http://www.seaworld.org/animal-info/ info-books/walrus/conservation.htm (last visited Oct. 30,2012 ).

${ }^{65}$ CITES World, The Convention on International Trade in Endangered Species of Wild Fauna and Flora (Jul. 2003) http:// www.cites.org/eng/news/world/11.pdf

${ }^{66}$ Trade Measures in Multilateral Environmental Agreements, Supra. note 29.

${ }^{67}$ The CITES Secretariat, The Convention on International Trade in Endangered Species of Wild Fauna and Flora, http:// www.cites.org/eng/disc/sec/index.php (last visited Oct. 30, 2012).

${ }^{68} \mathrm{Id}$.

${ }^{69}$ Conference of the Parties, U.S. Fish \& Wildlife Service, http:// www.fws.gov/international/cites/conference-of-the-parties/ (last visited Oct. 30, 2012).

${ }^{70}$ Participation of Non-Governmental Organisations in International Environmental Governance: Legal Basis and Practical Experience, eco logic (Jun. 2002) http://www.ecologic.eu/ download/projekte/1850-1899/1890/report_ngos_en.pdf 
and reviewing national and international progress under the treaty. ${ }^{71}$ The COP meets every two and a half to three years to complete these responsibilities. ${ }^{72}$ To assist in the effective operation of the Convention, the COP established subsidiary bodies that include the Standing Committee and the Animals and Plants Committees. ${ }^{73}$

The CITES Secretariat receives policy guidance from the Standing Committee. ${ }^{74}$ The committee is made up of representatives from each of the six geographical regions (Africa, Asia, Europe, North America, Central and South America and the Caribbean, and Oceania). ${ }^{75}$ The Standing Committee meets on an "as needed" basis, which is usually twice a year. ${ }^{76}$ This committee is primarily responsible for overseeing the Secretariat's budget and for providing policy advice on the implementation of CITES. ${ }^{77}$

The Animals and Plants Committees are made up of experts. ${ }^{78}$ These two committees are responsible for reviewing categorization of species, drafting resolutions relating to animal and plant matters, and deciding when particular species are being exploited through trade. ${ }^{79}$ They meet twice between meetings of the Conference of the Parties and report to the Conference of the Parties

${ }^{71}$ CITES Conference of the Parties, Species Survival Network, http://www.ssn.org/cites_cop_EN.htm (last visited Oct. 30, 2012).

72 What is CITES and the CoP?, World Wide Fund Global, http:// awsassets.panda.org/downloads/what_is_cites_final_coc.pdf (last visited Oct. 30, 2012).

${ }^{73}$ Trade Measures in Multilateral Environmental Agreements, Supra. note 29.

${ }^{74}$ Standing Committee, U.S. Fish \& Wildlife Service, http://www. fws.gov/international/cites/committees/standing-committee. html (last visited Oct. 30, 2012).

${ }^{75}$ Standing Committee, The Convention on International Trade in Endangered Species of Wild Fauna and Flora, http://www. cites.org/eng/disc/sc.php (last visited Oct. 30, 2012).

${ }^{76}$ Standing Committee, U.S. Fish \& Wildlife Service, Supra. note 71.

77 Standing Committee, The Convention on International Trade in Endangered Species of Wild Fauna and Flora, Supra. note 72.

${ }^{78}$ Animals and Plants Committees, The Convention on International Trade in Endangered Species of Wild Fauna and Flora, http://www.cites.org/eng/disc/ac_pc.php (last visited Oct. 30, 2012).

${ }^{79} \mathrm{Id}$. during their meetings and, if requested, provide advice to the Standing Committee between such meetings. ${ }^{80}$

\section{Why the Current Approach is Inadequate to Deal with the Problem}

\section{A. Deficiencies in CITES}

"CITES is the single most important international instrument dealing with illegal trade in fauna and flora because it is the only treaty that requires Parties to penalize some aspects of illegal trade in protected species." ${ }^{{ }^{81}}$ It is the only international treaty that sets out specific violations relating to illegal activities in the wildlife and forestry sectors and enables countries to confiscate illegally sourced fauna and flora. ${ }^{82}$

Article II, paragraph 4 requires that: "The Parties shall not allow trade in specimens of species included in Appendices I, II and III except in accordance with the provisions of the present Convention." ${ }^{83}$ Therefore, Parties have the obligation to prohibit trade in CITES specimens whenever the Convention's conditions have not been complied with.$^{84}$ Article VIII, paragraph 1 supplements this general rule. ${ }^{85}$

Article VIII, paragraph 1 of CITES requires State Parties to criminalize and enforce any violation of CITES prohibitions. ${ }^{86}$ The treaty states: "These shall include measures: (a) to penalize trade in, or possession of, such specimens, or both; and (b) to provide for the confisca-

\footnotetext{
${ }^{80}$ Animals and Plants Committees, The Convention on International Trade in Endangered Species of Wild Fauna and Flora, http://www.cites.org/eng/disc/ac_pc.php (last visited Oct. 30, 2012)..

${ }^{81}$ Wildlife and Forest Crime Analytic Toolkit, The International Consortium on Combating Wildlife Crime (May 2012) http:// www.cites.org/eng/resources/pub/Wildlife_Crime_Analytic_ Toolkit.pdf

${ }^{82} \mathrm{Id}$.

${ }^{83}$ Text of the Convention, The Convention on International Trade in Endangered Species of Wild Fauna and Flora, http:// www.cites.org/eng/disc/text.php\#II (last visited Oct. 30, 2012).

${ }^{84}$ Cyrille de Klemm, Guidelines for Legislation to Implement CITES, the International Union for Conservation of Nature Environmental Policy and Law Paper No. 26 (1993) http:// data.iucn.org/dbtw-wpd/edocs/EPLP-026.pdf

${ }^{85} \mathrm{Id}$.

${ }^{86}$ Article VIII, Measures to Be Taken by the Parties, The Convention on International Trade in Endangered Species of Wild Fauna and Flora, http://www.cites.org/eng/disc/text. php\#VIII (last visited Oct. 30, 2012).
} 
tion or return to the State of export of such specimens." 87 However, this obligation does not itself create a criminal offence or provide any guidance as to the design of criminal offenses. Therefore, Article VIII, paragraph 1 of CITES would be classified as a non-self-executing provision because it could not be implemented in the United States until specific legislation has been adopted for that purpose. ${ }^{88}$ Unless expressly provided for by domestic legislation the obligations from the treaty cannot be enforced in the courts and penalties cannot be applied for non-compliance. ${ }^{89}$ (Self-executing provisions are directly applicable to a Party without a need for any additional national legal instrument.) ${ }^{90}$

The scope of this provision is quite broad and allows the Parties discretion on how to enforce the Convention. ${ }^{91}$ Some countries that are part of the treaty have not enacted specific legislation to implement the Convention. ${ }^{92}$ These countries instead rely on general wildlife and forest laws and sometimes use their Customs or foreign trade legislation to control trade in CITES species. ${ }^{93}$ However, these laws usually do not have the specific purpose of implementing CITES because they were enacted before the treaty was formed. ${ }^{94}$ Without national legislation to provide basic implementation of the CITES, it becomes difficult both to prevent criminal groups from engaging in the illegal trade in wildlife species and to punish the perpetrators. ${ }^{95}$ This greatly diminishes the effectiveness of the CITES treaty and shows that CITES can only be as effective as the specific provisions that are enforced. ${ }^{96}$ So, even though CITES is widely implemented (even if not to its fullest extent) it is not able to control every aspect of the illegal trade in endangered species. ${ }^{97}$

${ }^{87} \mathrm{Id}$.

${ }^{88}$ Klemm, Supra. note 81.

${ }^{89} \mathrm{Id}$.

${ }^{90} \mathrm{Id}$.

${ }^{91} \mathrm{Id}$.

${ }_{92}$ Wildlife and Forest Crime Analytic Toolkit, Supra. note 78.

${ }_{93} \mathrm{Klemm}$, Supra. note 81.

${ }^{94} \mathrm{Id}$.

${ }^{95}$ Wildlife and Forest Crime Analytic Toolkit, Supra. note 78.

${ }^{96} \mathrm{Id}$.

${ }^{97}$ Duncan Brack, Kevin Gray and Gavin Hayman, Controlling the International Trade in Illegally Logged Timber and Wood Products, Royal Institute of International Affairs (Feb. 2002) http://www.chathamhouse.org/sites/default/files/public/Research/Energy,\%20Environment\%20and\%20Development/ tradeinillegaltimber.pdf
Some experts have even stated that listing species by their vulnerability to extinction can have a negative effect "because it may promote, as opposed to curb, the illegal trade in species by inadvertently advertising their rarity."98 This is why there need to be clear and stringent control mechanisms and enforcement action. ${ }^{99}$

\section{B. A Growing Problem}

The United Nations reported, on the basis of more in-depth research, that criminal organizations have diversified into the illegal markets for fauna and flora, and that even when an organized crime group is not involved the trafficking, it is still highly organized. ${ }^{100}$ It is believed they are attracted by the high profits associated with wildlife trafficking. ${ }^{101}$

Organized criminal rings that smuggle exotic wildlife across national borders repeatedly violate laws. ${ }^{102}$ The perpetrators display the characteristics of organized crime groups such as the use of violence, corruption and extortion to acquire and traffic in the wildlife. ${ }^{103}$ The organized criminal groups that are in the illegal wildlife trade generally fall into three categories. ${ }^{104}$

First, there are groups of local farmers that sell species illegally to increase their incomes. ${ }^{105}$ Income from illegal wildlife poaching and trading is a way for impoverished hunters and traders from developing countries to generate incomes. ${ }^{106}$ Some of the indigenous people consider hunting these animals a part of their culture, religion, or

${ }^{98}$ Erika Alacs and Arthur Georges, Wildlife across our borders: a review of the illegal trade in Australia, Australian Journal of Forensic Sciences, vol. 40, No. 2 (Dec. 2008) http://piku.org. au/reprints/2008_Alacs_Aust_J_Forensic_Sci.pdf

${ }^{99}$ Wildlife and Forest Crime Analytic Toolkit, Supra. note 78.

${ }^{100}$ Illicit trafficking in protected species of wild flora and fauna and illicit access to genetic resources, Economic and Social Council of the United Nations (Mar. 4, 2003) http://www.unodc.org/ pdf/crime/commissions/12_commission/8e.pdf

${ }^{101} I d$.

${ }^{102}$ Mara E. Zimmerman, The Black Market for Wildlife: Combating Transnational Organized Crime in the Illegal Wildlife Trade, 36 Vand. J. Transnat'l L. 1657, 1668 (2003)

${ }^{103}$ Illicit trafficking in protected species of wild flora and fauna and illicit access to genetic resources, Supra. note 97.

${ }^{104}$ Zimmerman, Supra. note 99 at 1668.

${ }^{105}$ Nicole Veash, In Brazil, Web Weaves Illegal Trade; Animal Dealers Find a Home on the Internet, The Boston Globe (Oct. 31, 1999) http://www.highbeam.com/doc/1P2-8572659.html (last visited Oct. 30, 2012).

${ }^{106}$ Liana Sun Wyler and Pervaze A. Sheikh, International Illegal Trade in Wildlife: Threats and U.S. Policy, Congressional Research Service (Mar. 3, 2008) http://fpc.state.gov/documents/ organization/102621.pdf 
traditions. ${ }^{107}$ Second there are larger, Mafia-style groups that purchase species from destitute peasants and sell them at a large profit. ${ }^{108}$ Finally, the most detrimental are the international smuggling rings. ${ }^{109}$

Regardless, the illegal wildlife trade network includes any combination of the following:

(1) village hunters, who trade small wildlife as a source of subsistence cash income or who kill some wildlife to protect their people and crops from attacks; (2) wildlife experts; (3) criminal entities, sometimes including terrorists, rebels, drug traffickers, and others, able to evade detection, and transport and secure the products, as well as launder the proceeds; (4) legitimate businesses serving as a front for the trade; (5) corrupt government officials to facilitate import and export; and (6) consumers willing to pay for the contraband. ${ }^{110}$

As globalization has improved the ease of travel, transport, transactions, and other cross-border barriers that previously limited wildlife trade, it has now opened a variety of trafficking pathways. ${ }^{111}$

In recent years, officials from U.S. Fish and Wildlife Service (US FWS) and Interpol, have recognized a growth in the scope, sophistication, and organization of wildlife crime. ${ }^{12}$ Investigations show that these crimes involve "multiple suspects in multiple locations committing multiple felonies" according to a US FWS report. ${ }^{113}$ Organized groups will keep operating across state lines and international borders because of the profits. ${ }^{114}$ These groups have the financing and technology to identify new markets and complete transactions. ${ }^{115}$

\section{A New approach}

${ }^{107}$ Liana Sun Wyler and Pervaze A. Sheikh, International Illegal Trade in Wildlife: Threats and U.S. Policy, Congressional Research Service (Mar. 3, 2008) http://fpc.state.gov/documents/ organization/102621.pdf

${ }^{108}$ Veash, supra. note 102; see also CITES Seeks Stronger Action Against Organized Wildlife Criminals, Convention on International Trade in Endangered Species of Wild Fauna and Flora (Nov. 6, 2012) http://www.cites.org/eng/news/ pr/2002/021106_illegaltrade.shtml (last visited Oct. 30, 2012).

${ }^{109} \mathrm{Id}$.

${ }^{110}$ Wyler, Supra. note 103.

${ }^{111} I d$.

${ }^{112} I d$.

${ }^{113}$ Office of Law Enforcement Strategic Plan 2006-2010, U.S. Fish \& Wildlife Service, (Dec. 2005) http://www.fws.gov/le/pdf/ OLEStrategicPlanDec2005.pdf (last visited Oct. 30, 2012).

${ }^{114} I d$.

${ }^{115} I d$.
On July 25, 2012, there were new and innovative ideas disseminated to countries to help them better battle environmental crime. ${ }^{116}$ These ideas were called: "Wildlife and Forest Crime Analytic Toolkit." 117 "The use of the Toolkit will provide government officials, Customs, police and other relevant enforcement agencies with a framework to analyze, prevent, detect and combat wildlife and forest offences." 118 This should enable countries to increase their abilities to effectively fight environmental crimes. ${ }^{119}$

The toolkit is organized into five parts: (1) Legislation, (2) Enforcement, (3) Judiciary and Prosecution, (4) Drivers and Prevention, and (5) Data and Analysis. ${ }^{120}$ Each part addresses comprehensively key issues that need to be examined. ${ }^{121}$ This is so the users can analyze "root causes of crime, preventive mechanisms and responses of the criminal justice system." ${ }^{122} \quad$ However, the Toolkit does not cover every aspect of each country's legal system and each country will need a tailor-made approach after their assessment of their situation. ${ }^{123}$ It is also just a first version and will need to be improved and developed. ${ }^{124}$ The Toolkit provides a great variety of tools but, it is still a work in progress. ${ }^{125}$

\section{Models for Defining and Prosecuting International Crimes}

Since, illegal wildlife trade is part of organized crime in many countries it needs international solutions. Three ways of handling this international problem are: (1) by applying existing international mechanisms; (2) by holding participants accountable on an international criminal level or, (3) by enacting new mechanisms to combat it. The likely success of each of these methods is considered in the following sections.

\section{a. The Convention Model}

\footnotetext{
${ }^{116}$ ICCWC launches wildlife and forest crime toolkit, Supra. note 3.

${ }^{117} I d$.

${ }^{118} I d$.

${ }^{119} \mathrm{Id}$.

${ }^{120}$ Wildlife and Forest Crime Analytic Toolkit, Supra. note 78.

${ }^{121} \mathrm{Id}$.

${ }^{122} I d$.

${ }^{123} \mathrm{Id}$.

${ }^{124} I d$.

${ }^{125} \mathrm{Id}$.
} 
The United Nations has tried to strengthen cooperation to combat transnational organized crime. ${ }^{126}$ In 2000, The United Nations Convention against Transnational Organized Crime was adopted by the General Assembly. ${ }^{127}$ Then in September 2003, it became the main international instrument for fighting against transnational organized crime when it entered into force. ${ }^{128}$ Finally, in 2012 at a meeting of the United Nations Convention against Transnational Organized Crime, environmental crime was recognized as a new form of transnational organized crime, which includes, illicit trafficking in wildlife. ${ }^{129}$

Wendy Elliott, WWF Global Species Program Manager stated: "Urgent action is now desperately needed to strengthen efforts to combat illicit wildlife trafficking at all levels of the trade chain." ${ }^{130}$ During the meeting, the United Nations Office on Drugs and Crime (UNODC) discussed wildlife traffickers' sophisticated techniques, along with how environmental crimes are associated with high levels of violence and corruption. ${ }^{131}$

The UNODC, with the purpose to "promote cooperation to prevent and combat transnational organized crime more effectively", ${ }^{132}$ encouraged countries to consider making trafficking of endangered species a serious crime. ${ }^{133}$ To be within the scope of the convention, the national legislation would have to define a "serious crime" as one which would constitute a "deprivation of liberty of at least four years or a more serious penalty." ${ }^{34}$ Since, traditionally minimal fines are imposed for wildlife crimes

\footnotetext{
${ }^{126}$ Zimmerman, Supra. note 99 at 1683.

${ }^{127}$ United Nations Convention against Transnational Organized Crime and the Protocols Thereto, United Nations Office on Drugs and Crime (Oct. 2012) http://www.unodc.org/unodc/ en/treaties/CTOC/index.html (last visited Oct. 30, 2012).

${ }^{128} I d$.

${ }^{129}$ llicit wildlife trafficking recognized as a new form of transnational organized crime, World Wide Fund Global (Oct. 22, 2012) http://wwf.panda.org/?206509/Illicit-wildlife-trafficking-recognized-as-a-new-form-of-transnational-organizedcrime (last visited Nov. 2, 2012).

${ }^{130} \mathrm{Id}$.

${ }^{131} I d$.

${ }^{132}$ United Nations Convention against Transnational Organized Crime and the Protocols Thereto, United Nations Office on Drugs and Crime (2004) http://www.unodc.org/documents/ treaties/UNTOC/Publications/TOC\%20Convention/ TOCebook-e.pdf

${ }^{133}$ Illicit wildlife trafficking recognized as a new form of transnational organized crime, Supra. note 127.

${ }^{134}$ United Nations Convention against Transnational Organized Crime and the Protocols Thereto, Supra. note 130.
}

and the majority of CITES parties do not have sanctions that deprive liberty, most national legislation does not meet the Convention's standards. ${ }^{135}$ If CITES parties either amend or enact legislation that follows the Convention's approach, then the U.N. Convention would be an effective international mechanism for combating transnational organized crime in the illegal wildlife trade. ${ }^{136}$ Stephanie Pendry, Enforcement Program Leader for TRAFFIC, stated Wildlife traffickers "are escaping justice because wildlife crime has not been regarded as a serious crime. But these criminal networks are having huge impacts, threatening not only wildlife, but also damaging communities, local economies and [the] rule of law." ${ }^{137}$

The U.N. Convention would be able to help wildlife crime be recognized as serious crime around the world. ${ }^{138}$ It would also guarantee that governments would help with the prevention of illegal wildlife trade internationally. ${ }^{139}$ Finally, more resources would be transferred to enforce CITES. ${ }^{140}$ If illegal wildlife trade were covered under the U.N. Convention Against Transnational Organized Crime, then there would finally be a powerful international weapon for combating internationally organized wildlife crime. ${ }^{141}$

\section{b. The Ad Hoc Tribunal Model}

Ad-hoc international criminal tribunals were created to deal with the core international crimes, mainly genocide, war crimes and crimes against humanity. ${ }^{142}$ Should the international wildlife trade be looked at as a biological genocide? Unlike other instances of genocide, this one is not driven by hate or to do away with a disfa-

\footnotetext{
$\overline{{ }^{135} \text { Zimmerman, Supra. note } 99 \text { at } 1684 .}$

${ }^{136} \mathrm{Id}$.

${ }^{137}$ Illicit wildlife trafficking recognized as a new form of transnational organized crime, Supra. note 127.

${ }^{138}$ Zimmerman, Supra. note 99 at 1684.

${ }^{139} \mathrm{Id}$.

${ }^{140} I d$. at 1685 .

${ }^{141} I d$.

${ }^{142}$ Ad hoc tribunals, International Committee of the Red Cross http://www.icrc.org/eng/war-and-law/international-criminal-jurisdiction/ad-hoc-tribunals/index.jsp (last visited Oct. 30, 2012).
} 
vored group. ${ }^{143}$ These victims are animals with luxurious fur, brilliantly colored reptiles, and exotic flying creatures. ${ }^{144}$ Africa has been described as going through an elephant genocide. ${ }^{145}$ The elephants are being traumatized by mass slaughter due to culling. ${ }^{146}$

Are these reasons for an International Court for the Environment (ICE)? The ICE Coalition ${ }^{147}$ and the International Academy of Environmental Sciences (IAES) $)^{148}$ are organizations that feel it is. Wildlife trafficking problems cross international boundaries, but there is no International Court for the Environment to deal with them properly. ${ }^{149}$ Countries that attempt to solve the problems on their own fail due to a lack of institutional framework. ${ }^{150}$

To solve this problem, a specialized international judicial body could be formed. ${ }^{151}$ The court could hear and determine transnational environmental matters. ${ }^{152}$ This would also promote a greater agreement of the cur-

${ }^{143}$ Jonathan P. Kazmar, The International Illegal Plant and Wildlife Trade: Biological Genocide?, 6 U.C. Davis J. Int'l L. \& Pol'y 105, 106 (2000), also available at https://litigation-essentials. lexisnexis.com/webcd/app?action=DocumentDisplay\&crawl $\mathrm{id}=1 \&$ srctype $=$ smi\&srcid $=3 \mathrm{~B} 15 \&$ doctype $=$ cite $\&$ docid $=6+\mathrm{U}$. C. + Davis+J.+Int\%27l+L.+\%26+Pol\%27y+105\&key=0ec916d 53bc50ad31a14306ff96e22d7 (last visited Oct. 30, 2012).

${ }^{144} \mathrm{Id}$.

${ }^{145}$ Agony and Ivory, Elephant Advocacy http://elephantadvocacy.org/agonyandivoryreadmore.htm (last visited Oct. 30, 2012).

${ }^{146}$ Laurel Neme, The WildLife: Elephant Trauma \& Psychology, Gay Bradshaw, Pod Bean (Jan. 10, 2011) http://laurelneme. podbean.com/2011/01/10/the-wildlife-elephant-trauma-psychology-gay-bradshaw/ (last visited Nov. 2, 2012).

${ }^{147}$ ICE Tribunal, International Court for the Environment Coalition http://icecoalition.com/ice-tribunal (last visited Oct. 30, 2012).

${ }^{148}$ The Constitution of the European Environmental Criminal Court (EECC) and of the International Environmental Criminal Court (IECC), International Academy of Environmental Sciences (Jul. 2010) http://www.europarl.europa.eu/document/activities/cont/201007/20100714ATT78992/20100714 ATT78992EN.pdf

${ }^{149}$ Stephen Hockman QC, The Case for an International Court for the Environment, The Effectius Newsletter (Jun./Jul. 2011) http://effectius.com/yahoo_site_admin/assets/docs/InternationalCourtForTheEnvironment_StephenHockmanQC_Effectius_Newsletter14.21260322.pdf

${ }^{150} \mathrm{Id}$.

${ }^{151}$ Stuart A. Bruce, International Court for the Environment: The Road Ahead to Opening its Doors (Sept. 2012) http://icecoalition.com/wp-content/uploads/2012/09/ICE-The-RoadAhead-to-Opening-its-Doors.pdf

${ }^{152} I d$. rently fragmented international environmental laws. ${ }^{153}$ The Court would be setup for the primary purpose of resolving disputes from "customary and treaty-based environmental law." ${ }^{154}$

Mutual agreement would be "the quickest, cheapest and easiest way to establish the ICE." ${ }^{155}$ If parties were in a dispute, they would simply agree and consent to have the ICE tribunal handle their case. ${ }^{156}$ Then, it would be like the existing ad hoc arbitral tribunals. ${ }^{157}$ If the tribunal could be established without a treaty, it is predicted that it could be up and running within two years. ${ }^{158}$ Then it could be an example of what a court could do and could encourage a permanent ICE. ${ }^{159}$

The ICE Coalition thinks that the idea of an ICE Tribunal would be so beneficial that they have released a concept summary. ${ }^{160}$ The summary explains the role, process, and purpose of the ICE Tribunal. ${ }^{161}$ The summary describes how the tribunal would be similar to the International Chamber of Commerce's procedures for dispute resolution. ${ }^{162}$ It also states that the Parties will have to agree in advance that if international environmental law issues arise that they will go to the ICE tribunal. ${ }^{163}$ "Ad hoc international tribunals only provide for states as participants that have unequivocally agreed to the ad hoc international tribunal before it came into existence."164

The ICE Coalition also plans on the ICE tribunal publishing its own reports. ${ }^{165}$ This would then develop the corpus of international environmental law. ${ }^{166}$ The summary also brings attention to the fact that the tribunal

\footnotetext{
${ }^{153} I d$.

${ }^{154} I d$.

${ }^{155} \mathrm{Id}$.

${ }^{156} \mathrm{Id}$.

${ }^{157} I d$.

${ }^{158} \mathrm{Id}$.

${ }^{159} \mathrm{Id}$.

${ }^{160} \mathrm{http}$ ://icecoalition.com/ice-tribunal (follow "For more details on the role, process, and purpose of an ICE Tribunal, please see our note on the concept here." Hyperlink.)

${ }^{161} I d$.

${ }^{162}$ ICE Tribunal, International Court for the Environment Coalition (Aug. 2012) http://icecoalition.com/ice-tribunal (last visited Oct. 30, 2012).

${ }^{163} \mathrm{Id}$.

${ }^{164}$ Susan M. Hinde, The International Environmental Court: Its Broad Jurisdiction As A Possible Fatal Flaw, 32 Hofstra L. Rev. 727, 746 (2003), also available at (May 24, 2004) http://www. hofstra.edu/PDF/law_lawrev_hinde_vol32no2.pdf

${ }^{165} \mathrm{Id}$.

${ }^{166} I d$.
} 
would need to the media and governments in order to raise public awareness. ${ }^{167}$

Advocates of this tribunal believe certain issues regarding international environmental law will be solved. ${ }^{168}$ For example, the judges will need a level of expertise to make environmentally sound decisions. ${ }^{169}$ The ICE tribunal would also allow non-state entities to be parties. ${ }^{170}$

Since, environmental law is very broad it poses problems and complexities. ${ }^{171}$ So, if a decision is made at the ICE tribunal, it could have major effects on many different legal fields, such as international trade law, international human rights law, etc. ${ }^{172}$ This is because environmental claims usually intertwine with other international legal arguments. ${ }^{173}$

There could also be a problem with forum shopping. ${ }^{174}$ Since, international environmental law is such a broad subject matter; litigants would most likely be able to bring the lawsuit in several different courts. ${ }^{175}$ Therefore forum shopping would violate the legal system's goals of having ethical representation, efficiency and control over the law. ${ }^{176}$

So, if an International Court of the Environment were to be established there would need to be limitations. ${ }^{177}$ The court would need to make sure that its rulings do not weaken other international courts and make sure that its jurisdiction does not encourage forum shopping. ${ }^{178}$ In this way, an International Court of the Environment would meet the needs that brought it into ex-

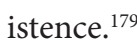

\section{c. The Treaty/Permanent Tribunal Model}

Another way to enforce the CITES treaty is by enacting new mechanisms to combat wildlife trafficking. Since there is no central enforcement entity, enforcement

\footnotetext{
${ }^{167} \mathrm{Id}$.

${ }^{168}$ Hinde, Supra. note 161 at 739.

${ }^{169} \mathrm{Id}$.

${ }^{170}$ ICE Tribunal, Supra. note 159.

${ }^{171}$ Hinde, Supra. note 161 at 748.

${ }^{172} \mathrm{Id}$.

${ }^{173} I d$. at 749 .

${ }^{174} \mathrm{Id}$. at 751 .

${ }^{175} \mathrm{Id}$.

${ }^{176} \mathrm{Id}$.

${ }^{177} I d$. at 756 .

${ }^{178} I d$.

${ }^{179} \mathrm{Id}$.
}

problems come up..$^{180}$ The Secretariat of CITES is the treaty's main authority and the treaty gives it no enforcement power. ${ }^{181}$ The treaty relies on the parties to setup enforcement because the authoritative body cannot. ${ }^{182}$ But since there is no specified penalty endorsed within CITES, parties interpret this provision in their laws, which usually impose only inadequate financial penalties. ${ }^{183}$ This causes a lack of uniformity because one country may have severe penalties, while another county's penalties for the same act may are practically nonexistent because they are so minor. ${ }^{184}$

The CITES treaty could be amended so that violations mean substantial financial penalties. ${ }^{185}$ This would encourage Parties to enforce national legislation. ${ }^{186}$ To make sure that the legislation was effective it would need to include the following elements: (1) the legislation must reflect that wildlife crime is serious, (2) it must define culpability clearly, (3) it must include extradition clauses, and (4) it must ensure wildlife crime receives as much funding as other illegal trade enforcement. ${ }^{187}$

First, legislation would have to show wildlife crime is serious and the penalties would need to reflect that fact. ${ }^{188}$ The problem right now is that wildlife crime is thought of as victimless and therefore the penalties are low. ${ }^{189}$ But, the whole world is a victim of the criminal wildlife trade because it causes environmental degradation. ${ }^{190}$ Therefore when countries have light penalties for wildlife crimes it treats them as if the offenses are victimless, when in fact they are not. ${ }^{191}$

\footnotetext{
${ }^{180}$ Saskia Young, Contemporary Issues of the Convention on International Trade in Endangered Species of Wild Fauna and Flora (Cites) and the Debate over Sustainable Use, 14 Colo. J. Int'l Envtl. L. \& Pol'y 167, 174 (2003), also available at (2003) http://www.cjielp.org/documents/cjielp_art66.pdf

${ }^{181} I d$.

${ }^{182}$ Terrence L. Lavy, Extradition in the Protection of Endangered Species, 4 Crim. L.F. 443, 448 (1993).

${ }^{183}$ Randi Alarcon, The Convention of International Trade in Endangered Species: The Difficulty in Enforcing Cities and the United States Solution to Hindering the Illegal Trade of Endangered Species, 14 N.Y. Int'l L. Rev. 105, 114 (2001).

${ }^{184} I d$. at 114.

${ }^{185}$ Zimmerman, Supra. note 99 at 1686.

${ }^{186} I d$.

${ }^{187} I d$. at 1675 .

${ }^{188} \mathrm{Id}$.

${ }^{189}$ Wildlife Criminals Targeted, BBC News (U.K.) (Apr. 22, 2002 at 12:41 GMT) http://news.bbc.co.uk/2/hi/uk_news/1943062. stm (last visited Oct. 30, 2012).

${ }^{190}$ Zimmerman, Supra. note 99 at 1676.

${ }^{191} I d$. at 1677.
} 
If legislation treated wildlife crime as a more serious crime, such as drug smuggling, then sanctions could be modeled from existing narcotics legislation. ${ }^{192}$ The amount of the fine could be in proportion to the contraband's total value. ${ }^{193}$ Amounts could be based on different factors such as the type of animal, its value and what the fine would be if it had been drugs instead. ${ }^{194}$ Also, imprisonment terms could be scaled based on the same criteria. ${ }^{195}$

An increase in the severity of the penalty would bring about a stronger deterrent. ${ }^{196}$ It would show that governments realize that wildlife trafficking is a serious problem. ${ }^{197}$ Even if CITES member states do not view wildlife crime with the same seriousness as narcotics crimes, criminal sanctions for violations of CITES still need to be increased and enforced. ${ }^{198}$

Second, culpability would need to be clearly defined. ${ }^{199}$ The definition of the culpability element is important in order to ensure that there are no loopholes in the law. ${ }^{200}$ Wildlife crimes tend to be classified as malum prohibitum. ${ }^{201}$ Black's Law Dictionary defines malum prohibitum as "an act that is a crime merely because it is prohibited by statute, although the act itself is not necessarily immoral." 202 Legislatures realize that an act might not be morally wrongful but could still gravely affect the public. ${ }^{203}$

A malum in se crime is "a crime or an act that is inherently immoral, such as murder, arson, or rape." ${ }^{204}$ Since these acts are regarded as inherently wrong, they require an element of mens rea. ${ }^{205}$ Evidence shows that the general

\footnotetext{
${ }^{192} I d$.

${ }^{193} \mathrm{Id}$.

${ }^{194} I d$.

${ }^{195} I d$.

${ }^{196} I d$.

${ }^{197} I d$. at 1678 .

${ }^{198} \mathrm{Id}$.

${ }^{199} I d$. at 1679

${ }^{200} \mathrm{Id}$.

${ }^{201}$ Michael Parker, Categorizing Environmental Crimes: Malum in Se or Malum Prohibitum?, 40 Tex. Envtl. L.J. 93, 103 (2010), also available at http://heinonline.org/HOL/Page?handle=hein.journals/ txenvlw40\&div=7\& g_sent=1\&collection=journals (last visited Oct. 30, 2012).

${ }^{202}$ MALUM PROHIBITUM, Black's Law Dictionary (9th ed. 2009), malum prohibitum

${ }^{203}$ Parker, Supra. note 201 at 97.

${ }^{204}$ MALUM IN SE, Black's Law Dictionary (9th ed. 2009), malum in se

${ }^{205}$ Parker, Supra. note 201 at 96.
}

population, by statistical data, considers environmental crimes to be not just regulatory crimes, but also immoral. ${ }^{206}$ Due to the severe harm environmental crimes cause, there should be harsher penalties as under the malum in se classification. ${ }^{207}$

Thirdly, due to the international smuggling rings there needs to be cooperation among governments. ${ }^{208}$ For example, when multiple international law enforcement agencies cooperated they were able to bring down one of the world's most notorious animal smugglers, Keng Liang "Anson” Won. ${ }^{209} \mathrm{Mr}$. Wong was believed to be responsible for smuggling more than 300 animals from Asia into the United States. ${ }^{210}$ It took the cooperation of multiple international law enforcement agencies to finally bring him to justice. ${ }^{211}$

In making legislation compatible it would be necessary to focus on the critical area of extradition. ${ }^{212}$ Extradition requires double criminality. ${ }^{213}$ Each country must provide criminal penalties for violations of the Convention because even if both parties are signatories to CITES, it does not make the offense criminal. ${ }^{214}$ If the Parties have not made it a criminal offense it becomes nearly impossible to prosecute, which defeats the purpose of fighting organized crime groups in the illegal wildlife trade. ${ }^{215}$ This will just encourage organized crime groups because they can operate in countries without extradition policies or adequate wildlife criminal legislation. ${ }^{216}$

However, extradition is governed by treaty in almost all countries and crimes have to be listed as extraditable offenses. ${ }^{217}$ "Under a schedule-type extradition treaty, a state seeking extradition must demonstrate that the de-

${ }^{206} I d$. at 107 .

${ }^{207} I d$. at 111 .

${ }^{208}$ Zimmerman, Supra. note 99 at 1680.

${ }^{209}$ Sting Investigation Captures Notorious Animal Smuggler, Animal Welfare Institute, http://labanimals.awionline.org/wildlife/wild-w98-99.html (last visited Oct. 30, 2012).

${ }^{210} I d$.

${ }^{211} I d$.

${ }^{212}$ Zimmerman, Supra. note 99 at 1680.

${ }^{213}$ Sharon A. Williams, The Double Criminality Rule and Extradition, 15 Nova L.Rev. 581 (1991), also available at (1991) http://heinonline.org/HOL/Page?handle=hein.journals/novalr $15 \&$ div $=32 \&$ g_sent $=1 \&$ collection $=$ journals (last visited Oct. 30, 2012).

${ }^{214}$ Zimmerman, Supra. note 99 at 1680.

${ }^{215} \mathrm{Id}$.

${ }^{216} I d$.

${ }^{217}$ Lavy, Supra. note 182 at 454. 
fendant is charged with an offense included in the treaty's schedule of offenses." ${ }^{218}$ This is similar to the double criminality principle. Both ways would make it easier to prosecute, whether the criminal was residing where the crime was committed or in another country. ${ }^{219}$

Finally, countries need resources to enforce wildlife laws. "Inadequate financial and human resources and lack of institutional capacity are barriers to enforcing these environmental laws." ${ }^{220}$ Substantial improvement could be achieved with more resources, such as the ability to arrest, indict, and convict. ${ }^{221}$ If authorities at the local, regional, and international levels cooperated together, they could easily enforce wildlife laws better than they do now. 222

Most countries limit the budget they allocate for environmental programs. ${ }^{223}$ This causes authorities to not be able to address illegal wildlife trafficking as efficiently as they could and also affects agencies by being inadequately staffed. ${ }^{224}$ Then enforcement suffers due to the staffs being inadequately trained and equipped. ${ }^{225}$

Corruption is another reason obstructing prosecution of wildlife crime. ${ }^{226}$ In some countries officials have been accused of working with organized criminals. ${ }^{27}$ The transfer of goods (endangered animals or products from endangered animals) becomes easier if there are high levels of corruption because customs services play a key role. ${ }^{228}$ Endangered species will continue to be illegally traded if there is no commitment from customs and enforcement bodies. ${ }^{229}$ It is obvious that not all CITES members have the resources to effectively improve efforts to fight wildlife crime. ${ }^{230}$ However the countries that are able to, should

\footnotetext{
${ }^{218} I d$.

${ }^{219}$ Zimmerman, Supra. note 99 at 1682.

${ }^{220}$ Dr. Bernard Irigia Kaaria and Ndica Lawrence Muchiri, Enforcement Challenges Across Borders: Detecting and Prosecuting Illegal Wildlife Trafficking, International Network for Environmental Compliance and Enforcement (2011) http:// inece.org/conference/9/proceedings/26_KaariaMuchiri.pdf

${ }^{221}$ Zimmerman, Supra. note 99 at 1682.

${ }^{222}$ Kaaria, Supra. note 223.

${ }^{223} \mathrm{Id}$.

${ }^{224} \mathrm{Id}$.

${ }^{225} \mathrm{Id}$.

${ }^{226} \mathrm{Id}$.

${ }^{227} \mathrm{Id}$.

${ }^{228} \mathrm{Id}$.

${ }^{229} \mathrm{Id}$.

${ }^{230}$ Zimmerman, Supra. note 99 at 1683.
}

look to the tools for combating the drug trade that have already proven successful. ${ }^{231}$

Another more involved mechanism would be to establish a permanent ICE done through an international treaty. ${ }^{232}$ It would have to be started as an recommendation at an UN General Assembly supported international conference. ${ }^{233}$ This would authorize the beginning of negotiations. ${ }^{234}$ Even though the ICE Coalition already has a draft constitution prepared, it is likely that negotiations will take some time before they agree on the final version. ${ }^{235}$ Then after the final agreement of how the treaty will be worded, it will have to be signed and ratified by a pre-determined number of states before it can become a new stand-alone court. ${ }^{236}$ The International Criminal Court is a prototype for the process. ${ }^{237}$

It would be a permanent institution. ${ }^{238}$ An ICE would "secure an effective international environmental regime" according to the draft. ${ }^{239}$ However, one difference between a tribunal and a permanent ICE would be that the permanent ICE would not have jurisdiction over nonState Parties. ${ }^{240}$ This Court could hold wildlife traffickers accountable for their crimes and help to integrate environmental governance regimes. ${ }^{241}$ The ICE would provide an ideal specialized dispute resolution and enforcement mechanism for CITES. ${ }^{242}$

\section{Conclusion: Which Model is Best Suited to Deal with this Problem?}

On March 3, 1973, the parties of CITES were primarily concerned with the conservation of a few well-

\footnotetext{
${ }^{231} I d$.

${ }^{232}$ Pathways to the court, International Court for the Environment Coalition http://icecoalition.com/the-court/pathwaysto-the-court (last visited Oct. 30, 2012).

${ }^{233}$ Bruce, Supra. note 147.

${ }^{234} I d$.

${ }^{235}$ Draft Constitution, International Court for the Environment Coalition (Sept. 2012) http://icecoalition.com/wp-content/ uploads/2012/09/Draft-Constitution1.pdf

${ }^{236}$ Bruce, Supra. note 147.

${ }^{237} I d$.

${ }^{238}$ Draft Constitution, Supra. note 239.

${ }^{239} \mathrm{Id}$.

${ }^{240} \mathrm{Id}$.

${ }^{241}$ International Court for the Environment Coalition (Nov. 2, 2012), http://icecoalition.com

${ }^{242} I d$.
} 
known species ${ }^{243}$ and never foresaw the expansion of CITES to cover hundreds of species of plant and animal life. The treaty itself is not capable of handling the complicated problems of the illegal wildlife trade. Combating these problems is the responsibility of individual member states and many of them have not enacted the necessary legislation or have not been enforcing it. This results in transnational organized criminal groups, which are able to smuggle exotic animals, plants, and their products in and out of states with ease. The lack of environmental enforcement against violators of wildlife legislation makes the illegal wildlife trade highly attractive with little risk of prosecution and conviction.

Organized crime participating in wildlife trafficking is a threat to endangered species and biodiversity. Each state member of CITES must enact legislation that is not only sufficient to implement the basic provisions of the treaty, but also provides for severe criminal sanctions against wildlife criminals to acknowledge the seriousness of these crimes. There have been several proposals for enforcement mechanisms on the international level, including (1) The Convention Model, (2) The Ad Hoc Tribunal Model, or (3) The Treaty/ Permanent Tribunal Model.

Currently, the U.N. Convention against Transnational Organized Crime seems to be the most effective mechanism combating transnational organized crime in the illegal wildlife trade. Since the Convention now recognizes environmental crime, now wildlife crime just needs to be classified as a "serious" crime. If CITES member states amended their legislation to provide for more severe penalties for violators of the treaty, then wildlife crime would be linked to the Convention. Therefore, combating transnational organized crime in the illegal wildlife trade with additional resources made available under the Convention.

However, The Ad Hoc Tribunal Model seems like it would be more effective. An International Court for the Environment could properly deal with wildlife trafficking problems that cross state lines, and would also unify international environmental laws. The judges would have a level of expertise to make environmentally sound decisions to protect endangered animals and biodiversity.
Eventually, the Ad Hoc Tribunal could also lead the way for a permanent ICE.

One day transnational organized criminal participation in the illegal wildlife trade will stop. The only question is: Will it be because of the efforts of the global community to stop illegal wildlife trafficking or will it be because the criminal rings have nothing to sell because of the extinction plant and animal species? 